\title{
THE INTERNATIONAL TRADE IN THE RELATIONSHIP BETWEEN FINANCIAL LEVERAGE AND PERFORMANCE: A CASE IN VIETNAM
}

\author{
NGUYEN HOANG THUY BICH TRAM, TRAN THI THUY LINH, TON NU NHAT MINH \\ University of Economics Ho Chi Minh city
}

nhtbtram@ueh.edu.vn,linhtcdn@ueh.edu.vn,nhatminh291195@gmail.com

\begin{abstract}
This paper considers the international trade effect in the relationship between financial leverage and firm performance. It find out the answer to whether the impact of the financial leverage on internationally - oriented firms are stronger than on domestically - oriented ones. The paper use ordinary least squares, two - stage least squares and generalized method of moments to analyze data sample consisting of 107 enterprises in the period 2007-2015. Research results show that the international trade affects negatively the relationship between financial leverage and performance in Vietnamese firms. The effect of financial leverage in internationally - oriented firms are more than in domestically - oriented firms. Besides, other factors such as Vietnam's interest rate, firm age, and firm size also affect negatively on firms' performance. However, economic growth factor has a positive impact on the increase of assets' return. In addition, the research points out that the large scale of business will offset the negative effects of financial leverage on performance.
\end{abstract}

Keywords. Financial leverage, international trade, performance..

\section{INTRODUCTION}

Financial leverage is formed when a company decided to buy property or to invest by debt with the purpose of increasing profitability. However, financial leverage is the double edge blade knife, just as a positive tool for amplifying net profit, at the same time, as a negative tool that causes higher financial risk. The success or the failure of every company depends on choosing capital structure. This will increase or reduce the financial risk. Reviewing and analyzing the use of financial leverage in Vietnam has important implications for managers in the direction and mobilization of resources for Vietnamese business. The specific evidence in 2008 and earlier 2009, Vietnam suffered the global financial crisis from the United States of America. Vietnamese stock market was in dismal state, in which investors were not well-off capital in that time. In this situation, the Government of Vietnam launched the economic stimulus package on March 2009. Many securities firms accepted the financial leverage ratio up to 50\%, even some securities companies offered loans from $60 \%-80 \%$ for their big customers. As the results of that, Vietnamese stock market had high liquidity by the sudden increase of investing cash flow into stocks. This movement of government not only helps the securities firms have a strong breakthrough of brokerage market share, but also helps investors be more optimistic.

Financial leverage is now not only applied to large enterprises in developed countries but also becomes popular to the small and medium enterprises in the country which is moving from a centralized economy to a market economy like Vietnam. In the process of strong globalization, most of Vietnamese companies also apply to the external funding policies to support business activities and amplify higher income for investors. In the past years, Vietnam has been participating in regional economic organizations such as WTO, ASEAN, APEC, and TPP, so, it is not astonishing when most enterprises in Vietnam are involved in import and export activities (also known as the internationally-oriented enterprises). Besides, Vietnam still has domestically-oriented enterprises which is not involved in importexport operations, only produce and distribute products in domestic market.

The big question is whether the internationally-oriented enterprises use financial leverage more effectively than the domestic-oriented enterprises. The research of funding policy in these enterprises plays an important role in improving their performance in the future. In Vietnam, there are some paper about the impact of financial leverage on enterprises' performance, such as [1] researched on the relationship between growth opportunities and financial leverage in Vietnam, [2] tended to financial 
leverage, corporate growth and financial strength of the listed companies on Ho Chi Minh City securities trading center, [3] also assessed the situation of using leverage in non-financial enterprises listed in Vietnam, and so on. However, these researches haven't clarified about the influence of international trade on the relationship between financial leverage and performance. That motivates us to implement the topic.

Interestingly, our paper shows that the negative effects of financial leverage on the performance of international - oriented firms will be more powerful than the one of domestic - oriented firms, but if the greater scale of business will help to reduce the negative impact for Vietnamese firms. We also notice that the Vietnamese firms are still quite nascent, and being in the early stage of reaching international markets. Therefore, it is unavoidable the fierce competition on the global environment, arising in transaction costs and management, and market fluctuations. These things, sometimes, increase the real burden than as a good opportunity for businesses in the short term.

This research brings a new perspective on the business development orientation, in which, the participation in export - import activities related to external funding policy will influence on the business outcome. It contributes to help managers have better understand about the influence of international activities, and then, make the right decision on funding policy to bring good growth results for their business in the future. This research is regarded as the first step, open a new direction for further research on this issue.

The paper is divided into five sections. First, we review other papers related on the impact of financial leverage and internationalization on firm's performance. Second, we build up the model and then, present the analysis of regression results in section four. Finally, we come to conclusion and give policy implications.

\section{LITERATURE REVIEW}

\subsection{The impact of financial leverage on performance}

[4] said that leverage has positive impact on the enterprise performance. However, [5] showed that the changes in financial leverage affect negatively on stock profits. Similarly, [6] showed that reducing the use of financial leverage will bring better results for business. [7] also provided the empirical evidence to support for the negative relationship between financial leverage and performance. Besides, the neutral standpoint of [8] pointed out that the change in leverage doesn't affect performance.

Some papers also show the impact of financial leverage on performance is not significant. A typical example, [9] showed that the positive relationship will exist at the certain point of financial leverage and beyond that critical threshold is the negative effect. In addition, financial leverage is also related to enterprises' growth in the future. For example, [10] said that financial leverage has positive influence to the growth of companies in the future. However, there are still some mixed views around the problem.

The impact of financial leverage on performance is also studied in developed and developing countries. For example, [11] showed the positive relationship in Russia. However, [12] found out the negative effect of debt on firm performance in Romani. The same results of [12] is also found in [13] which is conducted in Pakistan, and [14] in Kenya. [15] gave a different conclusion when implementing in 170,013 private firms in Thailand. The effect depends on firm's size which is positive for small firms and negative for large firms.

In summary, we can see clearly three main views about the relationship between financial leverage and performance, that is: (i) the reverse relationship between them; (ii) the positive relationship between them; (iii) no relationship between them.

\subsection{The impact of internationalization on performance}

When many developed and developing countries in the world are moving toward expanding globalization, enterprises in these countries have become the main driving force of this process. Thus, many researchers have implemented experimental researches revolved around the relationship between internationalization and firm's performance. However, the answer is still relatively vague due to the differences between the results of previous researches. 
The views of [16], [17], [18], [19] are that the internationally - oriented companies, engaged in import and export activities will enjoy the benefits from the internationalization, so their performance is often better than domestic enterprises. Over times, the process of internationalization helps enterprises access to external funding such as the resources of knowledge that they might not have before. [20] argue that the knowledge resources (for example, technology, marketing, and management skills) as well as the available assets and capital have the significant and positive impact on the growth of multinational companies. [21] also provided extremely persuasive empirical evidence to prove that when companies had the ability to penetrate export markets, they will improve their performance in the future. In addition, [22], [19], [23] also said that the internationalization will positively influence to enterprises' performance. However, it should be noted, recently, the research of [24] also has been attended as it gives the view that the leverage rate of the multinational companies is not significantly lower than the one of domestic business after controlling the characteristic variables of multinational companies.

On the other hand, some other scholars argue that the process of internationalization caused a negative impact on the performance of business. According to [25], and [26], enterprises participating in international markets must face many disadvantages such as the fierce competition, transaction costs, management problems, market fluctuations and the diversity of culture and preferences.

Besides, some researches also give reason explaining for the negative effect in the internalization process. [27] showed that the relationship between internalization and long - term performance has inverted U sharp when they conducted research in the developed country - Spanish. They pointed out that technology can speed up long - term performance in the first stage, but the experience of international business can flatten it. [28] showed the important role of social networks and dynamic internationalization capabilities in the performance of SMEs in low - tech countries. They confirmed that these factors give positive effects on the international performance of enterprises. Another research of [29] is conducted in Korean SMEs. They also realized that some factors like technological resources, executives' managerial capabilities and subcontracting customer networks will help to enhance exports in these companies. [30] showed that foreign technology and professional services have positive effects on firm performance in India. However, these effects are dependent on size, growth and slack resources. Interestingly, they found that offshore outsourcing give more positive affect in small firms with high growth rate and financial slack than in large firms. Therefore, the effect of internalization on firm's performance is also dependent on its characteristics and high quality human resources [31].

[32] also implemented the research about the relationship between the process of internationalization and the performance of manufacturing enterprises from 2007 to 2012 in Vietnam. The research results showed an S-shaped relationships between internationalization and performance with three different stages. First stage, decreasing the initial performance can come from the legal barriers, insufficient market knowledge and the initial costs of the process of international integration. Second stage is the improvement of enterprises' performance. The costs of globalization process is gradually being offset by the greater benefits after expanding business market and achieve scale economics. Then, the performance still falls back at the higher level than the benefit form internationalization. This proves that transaction costs, management as well as market diversity are out of control when the internationalization transcends the optimal threshold.

Briefly, these authors have just given evidence of the relationship between financial leverage and performance or the internationalization effect on performance. These studies still haven't clarified the interaction between these three problems by quantitative methods. With the above arguments, the relationship between leverage and performance can be different between domestic-oriented companies and international-oriented companies. This puts a big question whether the international trade would influence negatively on the relationship between financial leverage and performance. To overcome the limitations, this paper will demonstrate clearly the relationship between financial leverage, internationalization and performance for non-financial companies listed on Vietnam's stock trading floor. 


\section{METHODOLOGY}

\subsection{Data}

The data of 107 Vietnamese non-financial companies are collected from audited financial reports in the period 2007-2015, all lumped into 963 observation data set. Macroeconomic variables are retrieved from the State Bank of Vietnam and the International Monetary Fund (IMF).

\subsection{Model}

Our paper will assess the influence of internationalization process on the relationship between financial leverage and performance. It is expected to clarify the difference between the performance of the domestically-oriented and internationally-oriented enterprises in 2 steps.

In the first stage, the paper regresses the following model to retrieve the expected financial leverage values:

$$
\text { LEV }_{\mathrm{i}, \mathrm{t}}=\boldsymbol{\beta}_{0}+\boldsymbol{\beta}_{1} * \mathrm{INT}_{\mathrm{t}}+\boldsymbol{\beta}_{2} * \mathrm{GDP}_{\mathrm{t}}+\boldsymbol{\beta}_{3} * \mathrm{AGE}_{\mathrm{i}, \mathrm{t}}+\boldsymbol{\beta}_{4} * \mathrm{SIZE}_{\mathrm{i}, \mathrm{t}}+\boldsymbol{\beta}_{5} * \operatorname{TANGIBILITY}_{\mathrm{i}, \mathrm{t}}+\boldsymbol{\beta}_{6} * \operatorname{IND}_{\mathrm{i}, \mathrm{t}}+\varepsilon_{\mathrm{i}, \mathrm{t}}(\mathbf{1})
$$

Where:

- TANGIBILITY ${ }_{\mathrm{i}, \mathrm{t}}$ : the ratio of the net fixed assets on total assets of company $\mathrm{i}$ in year $\mathrm{t}$.

- $\mathrm{INT}_{\mathrm{t}}$ : the average of Vietnamese base interest rate in year $\mathrm{t}$.

- GDP $\mathrm{t}_{\mathrm{t}}$ the growth of total domestic product in year $\mathrm{t}$.

- $\mathrm{AGE}_{\mathrm{i}, \mathrm{t}}$ : the age of company $\mathrm{i}$ is measured by the logarithm of the number of years since the company was established.

- $\mathrm{SIZE}_{\mathrm{i}, \mathrm{t}}$ : company size is measured by using the logarithm of the total assets of company $\mathrm{i}$ in year $\mathrm{t}$.

- $\mathrm{IND}_{\mathrm{i}, \mathrm{t}}$ : a set of dummy variables according to industry sector.

$-\mathrm{LEV}_{\mathrm{i}, \mathrm{t}}$ : the ratio of total liabilities on total assets

In the second stage, the expected value of financial leverage in equation 1 will be used as a variable to test how the leverage impacts on performance, based on the following regression model:

$$
\mathbf{R O A}_{\mathrm{i}, \mathrm{t}}=\boldsymbol{\beta}_{0}+\boldsymbol{\beta}_{1} * \mathrm{INT}_{\mathrm{t}}+\boldsymbol{\beta}_{2} * \mathrm{GDP}_{\mathrm{t}}+\boldsymbol{\beta}_{3} * \mathrm{AGE}_{\mathrm{i}, \mathrm{t}}+\boldsymbol{\beta}_{4} * \mathrm{SIZE}_{\mathrm{i}, \mathrm{t}}+\boldsymbol{\beta}_{5} * \operatorname{IVLEV}_{\mathrm{i}, \mathrm{t}}+\boldsymbol{\beta}_{6} * \mathrm{IND}_{\mathrm{i}, \mathrm{t}}+\varepsilon_{\mathrm{i}, \mathrm{t}}(2)
$$

Where:

- IVLEV $\mathrm{V}_{\mathrm{i}, \mathrm{t}}$ the expected value of financial leverage for company $\mathrm{i}$ in year $\mathrm{t}$.

- $\mathrm{ROA}_{\mathrm{i}, \mathrm{t}}$ : the representative variable for the performance of company $\mathrm{i}$ in year $\mathrm{t}$ is measured by the ratio of profit after tax on total assets.

To test whether the impact of leverage on performance in internationally-oriented companies is stronger than domestically-oriented companies, we estimate the following model:

$$
\underset{\beta_{7} * \operatorname{IND}_{\mathrm{i}, \mathrm{t}}+\varepsilon_{\mathrm{i}, \mathrm{t}}}{\mathbf{R O A}_{\mathrm{i}}}=\boldsymbol{\beta}_{0}+\boldsymbol{\beta}_{1} * \mathbf{I N T}_{\mathrm{t}}+\boldsymbol{\beta}_{2} * \mathrm{GDP}_{\mathrm{t}}+\boldsymbol{\beta}_{3} * \mathrm{AGE}_{\mathrm{i}, \mathrm{t}}+\boldsymbol{\beta}_{4} * \mathrm{SIZE}_{\mathrm{i}, \mathrm{t}}+\boldsymbol{\beta}_{5} * \mathrm{IVLEV}_{\mathrm{i}, \mathrm{t}}+\boldsymbol{\beta}_{6} * \mathrm{IVLEV}_{\mathrm{i}, \mathrm{t}} * \mathrm{INTER}_{\mathrm{i}, \mathrm{t}}+
$$

Where:

- INTERi,t: Binary variables have value 1 for internationally-oriented companies (companies involved with import activities, export activities or both) and value 0 for domestically-oriented companies.

A problem encountered in this study is endogenous variable LEV in the equation (2). To control this problem, the paper used instrument variable TANGIBILTY based on Vithessonthi and Tongurai (2015) [15]. Besides, GDP and base interest rate variables can be impacted by each other. Therefore, OLS estimate is no longer consistent, so, GMM (Generalized Methods of Moments Estimators) and 2SLS (two Stage Least of Square) are the appropriate methods used to estimate in this paper.

The paper is followed these steps:

- Step 1: testing whether LEV is endogenous or not by regression equations (1) and create residuals e. Then, we regress equation (2) with e. Finally, we test hypothesis H0: e $=0$ (LEV is 
not endogenous) and $\mathrm{H1}: \mathrm{e} \neq 0$ (LEV is endogenous). If LEV was endogenous, we would use TANGIBILTY as an instrument variable and run 2SLS and GMM models to overcome.

- Step 2: Creating IVLEV variable by regressing equation (1) and create IVLEVINTER = IVLEV * INTER

- Step 3: Estimating the pools OLS, 2SLS and GMM for equations (2) and (3).

\section{RESULTS}

\subsection{Descriptive statistics and diagnostic tests}

Table 1: Descriptive statistics of the variables in the model.

\begin{tabular}{lccccc}
\hline \multicolumn{1}{c}{ Variables } & Obs & Min & Mean & Max & $\begin{array}{c}\text { Standard } \\
\text { deviation }\end{array}$ \\
\hline ROA & 963 & -0.65 & 0.09 & 1.58 & 0.12 \\
LEV & 963 & 0 & 0.42 & 0.93 & 0.23 \\
LNAGE & 963 & 0 & 2.82 & 4.14 & 0.72 \\
SIZE & 963 & 23.22 & 26.95 & 35.76 & 1.62 \\
TANGIBILITY & 963 & -0.71 & 0.2 & 2.17 & 0.19 \\
\hline
\end{tabular}

As we can see, the debt ratio of the Vietnamese non-financial enterprises is about $42 \%$ on average, however, the disparity between these companies on the sample in fairly large, in which the maximum debt ratio is approximately $93 \%$ and the minimum is approximately $0 \%$. The scale of enterprises in the sample are also quite homologous, the difference between the max and min values is not high. The remaining variables show the large gap between the smallest and largest values. The below table will demonstrate that the correlation between these variables is rather small.

Table 2 : The correlation matrix of variables

\begin{tabular}{llllll}
\hline & ROA & LEV & LNAGE & SIZE & TANGIBILITY \\
\hline ROA & 1 & & & & \\
LEV & -0.3236 & 1 & & & \\
LNAGE & -0.0068 & -0.0566 & 1 & & \\
SIZE & -0.0449 & 0.1049 & 0.0309 & 1 & \multicolumn{1}{c}{ Source: calculated by the authors } \\
TANGIBILITY & 0.0121 & -0.0443 & -0.0359 & 0.0388 & \\
\hline
\end{tabular}

Next, we will run endogenous test for LEV variable. The paper will retrieve residuals from equation 1 which expresses expected financial leverage, then continue to regress the residuals in equation 2 to test endogeneity for financial leverage variable. These pre-estimations is to ensure the consistence of research results. The results of the regression equation (2) with residuals is as table 3 .

As we can see, $\mathrm{e}=0.6245 \neq 0$ and $\mathrm{p}$ value $=0.08<10 \%$, so we accept H1: LEV is endogenous. Next, we also conduct multi-collinearity test. Based on the VIF criteria in the following table, VIF < 10 indicates the variables are completely independent with each other, which is suitable for regression in the model. The table result is as table 4. 

AND PERFORMANCE: A CASE IN VIETNAM

Table 3: The results of endogeneity for expected financial leverage

\begin{tabular}{|c|c|c|c|c|c|c|}
\hline ROA & Coef & Std.Err & $\mathbf{T}$ & $P>|t|$ & $95 \%$ Conf. & Interval] \\
\hline INT & -0.9671876 & 0.3939058 & -2.46 & 0.014 & -1.740208 & -0.194167 \\
\hline GDP & 0.2354325 & 0.4271436 & 0.55 & 0.582 & -0.602816 & 1.073681 \\
\hline LNAGE & -0.0112116 & 0.0069497 & -1.61 & 0.107 & -0.02485 & 0.0024268 \\
\hline SIZE & 0.0104202 & 0.0065951 & 1.58 & 0.114 & -0.002522 & 0.023606 \\
\hline LEV & -0.7944708 & 0.3561192 & -2.23 & 0.026 & -1.493337 & -0.0956 \\
\hline IND & 0.0000748 & 0.000442 & 1.69 & 0.091 & -0.000012 & 0.00016 \\
\hline $\mathbf{E}$ & 0.6245368 & 0.3562223 & 1.75 & 0.080 & -0.074532 & 1.32306 \\
\hline Constant & 0.2280352 & 0.079328 & 2.86 & 0.004 & 0.0715634 & 0.384507 \\
\hline $\begin{array}{l}\text { Obs } \\
\text { Adj. R-sq } \\
\text { F test } \\
\text { P value }\end{array}$ & \multicolumn{6}{|c|}{$\begin{array}{c}963 \\
0.1076 \\
17.58 \\
0.000\end{array}$} \\
\hline
\end{tabular}

Source: calculated by the authors

Table 4: Results of multicollinearity test

\begin{tabular}{ccc}
\hline Variables & VIF & $1 / \mathrm{VIF}$ \\
\hline SIZE & 1.08 & 0.928151 \\
LNAGE & 1.07 & 0.973937 \\
GDP & 1.03 & 0.974852 \\
LEV & 1.02 & 0.977103 \\
INT & 1 & 0.999216
\end{tabular}

\subsection{The impact of financial leverage to performance}

In table 5, columns 1 and 2 presents OLS regression result. Column 3 presents the results of firststage regression. Columns 4 and 5 present the results of second stage using TANGIBILITY as an instrument variable. Besides, the research also use Arellano-Bond test with AR (1) and AR (2), and Sargan test to ensure the fitness of the model. The results in columns 6 and 7 show that there are no autocorrelation level 2 in residuals and instrument variables are suitable which is expect to give reliable regression results in the models.

The results in 1-2 and 6 columns of table 5 show that regression coefficient LEV brings negative sign and has statistical significance ( $\mathrm{p}$ value $<1 \%$ ). It means that financial leverage has a negative impact on the performance of the Vietnamese enterprises in the period 2007-2015. This result is also consistent with the views of [33], [24], [8], [34]. The authors argue that using low leverage level will improve the results of business.

In column 7, the coefficient of variable LEV(IVLEV)*INTER brings negative sign and statistical significance. It means that the internationalization has a negative effect on the relationship between financial leverage and performance. In a related study [34], they insisted that the internationalization influences negatively the return on assets of export companies in India. Besides, the paper continues to check the robustness of the results research, aimed to demonstrate clearly the effects of internationalization on the relationship between financial leverage and performance. Therefore, we separate our research sample into two samples: domestic-oriented companies and international-orientated companies to study the relationship for both these companies. 

AND PERFORMANCE: A CASE IN VIETNAM

Table 5: The effect of financial leverage on firm's performance

\begin{tabular}{|c|c|c|c|c|c|c|c|}
\hline & (1) & (2) & (3) & (4) & (5) & (6) & (7) \\
\hline \multirow{2}{*}{ Variables } & OLS & OLS & IV-2SLS & IV-2SLS & IV-2SLS & GMM & GMM \\
\hline & & & First stage & $\begin{array}{l}\text { Second } \\
\text { stage }\end{array}$ & $\begin{array}{l}\text { Second } \\
\text { stage }\end{array}$ & & \\
\hline \multirow[t]{2}{*}{ INT } & $-0.688 * *$ & $-0.688^{*}$ & -0.444 & $-0.676^{*}$ & $-0.621^{*}$ & $-0.797 * * *$ & $-0.736 * * *$ \\
\hline & $(0.312)$ & $(0.312)$ & $(0.718)$ & $(0.398)$ & $(0.377)$ & $(0.240)$ & $(0.236)$ \\
\hline \multirow[t]{2}{*}{ GDP } & 0.605 & 0.601 & -0.639 & 0.622 & $0.718 *$ & $0.558 *$ & -0.469 \\
\hline & $(0.398)$ & $(0.396)$ & $(0.740)$ & $(0.446)$ & $(0.387)$ & $(0.303)$ & $(0.016)$ \\
\hline \multirow[t]{2}{*}{ LNAGE } & -0.003 & -0.003 & $-0.019 *$ & -0.002 & 0.002 & $-0.099 * * *$ & $-0.083 * * *$ \\
\hline & (0.009) & $(0.010)$ & $(0.010)$ & $(0.009)$ & $(0.008)$ & $(0.016)$ & $(0.016)$ \\
\hline \multirow[t]{2}{*}{ SIZE } & 0.000 & 0.000 & $0.017 * * *$ & -0.001 & -0.003 & $-0.016^{* * *}$ & $-0.012 *$ \\
\hline & $(0.003)$ & $(0.003)$ & $(0.005)$ & $(0.007)$ & $(0.003)$ & $(0.006)$ & $(0.006)$ \\
\hline \multirow[t]{2}{*}{ LEV (IVLEV) } & $-0.171 * * *$ & $-0.175^{* * *}$ & & -0.144 & & $-0.390 * * *$ & \\
\hline & $(0.019)$ & $(0.022)$ & & $(0.381)$ & & $(0.101)$ & \\
\hline \multirow[t]{2}{*}{ LEV(IVLEV)*INTER } & & 0.007 & & & -0.039 & & $-0.415 * * *$ \\
\hline & & $(0.012)$ & & & $(0.107)$ & & $(0.111)$ \\
\hline \multirow[t]{2}{*}{ TANGIBILITY } & & & -0.051 & & & & \\
\hline & & & $(0.038)$ & & & & \\
\hline \multirow[t]{2}{*}{ Constant } & $0.203 * * *$ & $0.205 * * *$ & & $0.202 * *$ & $0.186^{* *}$ & & \\
\hline & $(0.078)$ & $(0.078)$ & & $(0.081)$ & $(0.084)$ & & \\
\hline Number of observations & 963 & 963 & 963 & 963 & 963 & 963 & 963 \\
\hline Adj. R-sq & 0.106 & 0.105 & 0.019 & 0.103 & 0.023 & 0 & 0 \\
\hline BIC & -1435.919 & -1429.229 & -110.298 & 0 & 0 & 0 & 0 \\
\hline RSS & 12.075 & 12.073 & 47.832 & 12.109 & 13.194 & 0 & 0 \\
\hline \multirow[t]{4}{*}{ Arellano - Bond test } & AR (1) & & & & & -4.12 & -4.11 \\
\hline & $\mathrm{P}$-value & & & & & $(0.000)$ & $(0.000)$ \\
\hline & $\operatorname{AR}(2)$ & & & & & -1.94 & -2.17 \\
\hline & P-value & & & & & $(0.281)$ & $(0.319)$ \\
\hline Sargan test & & & & & & 32.37 & 31.58 \\
\hline$P$ value & & & & & & $(0.399)$ & $(0.437)$ \\
\hline
\end{tabular}

Symbol $* * *, * *$, and $*$ denote significance at the $1 \%, 5 \%$ and $10 \%$ level.

\subsection{The impact of financial leverage on performance in domestic-oriented firms and international- oriented firms}

In Table 6, GMM estimation results for domestically-oriented companies shows that coefficient LEV brings negative sign and has statistical significance ( $\mathrm{p}$ value $<1 \%$ ). This means that financial leverage increase will bring a decline in return on assets, similar to the results of [15]. Beside, in columns 6 , the financial leverage also has a negative impact to the performance of internationally-oriented firms. However, the absolute value of regression coefficient LEV in column $5(0.09)$ for domestically-oriented firms is smaller than the absolute value of LEV in column $6(0.23)$ for internationally-oriented firms. This shows that the negative impact of financial leverage in internationally-oriented firms will larger in domestically-oriented firms. This result is consistent with several studies such as [34], [35]. These authors claim that there is a negative linear relationship between internationalization and performance. The increase of international strategy will get a declining achievement in the future. Besides, the research also use Arellano-Bond test with AR (1) and AR (2), and Sargan test to ensure the fitness of the model. The pvalue of $\mathrm{AR}(2)$ tests are 0.631 and 0.405 that mean we cannot reject null hypothesis. We also conduct over - identifying restrictions test through Sargan test. The results in columns 5 and 6 show that there are no autocorrelation level 2 in residuals and instrument variables are suitable which is expect to give reliable regression results in the models. 

AND PERFORMANCE: A CASE IN VIETNAM

Table 6: The estimation results of domestic-oriented firms and international-oriented firms

\begin{tabular}{|c|c|c|c|c|c|c|}
\hline Variables & $\begin{array}{c}\text { (1) } \\
\text { First stage } \\
\text { (dependent } \\
\text { variable= } \\
\text { LEV) } \\
\text { Domestically- } \\
\text { oriented firms }\end{array}$ & $\begin{array}{c}(2) \\
\text { First stage } \\
\text { (dependent } \\
\text { variable= } \\
\text { LEV) } \\
\text { Internationally } \\
\text {-oriented firms }\end{array}$ & $\begin{array}{c}(3) \\
\text { Second stage } \\
\text { (dependent } \\
\text { variable = } \\
\text { ROA) } \\
\text { Domestically- } \\
\text { oriented firms }\end{array}$ & $\begin{array}{c}\text { (4) } \\
\text { Second stage } \\
\text { (dependent } \\
\text { variable = } \\
\text { ROA) } \\
\text { Internationally } \\
\text {-oriented firms }\end{array}$ & $\begin{array}{c}\text { (5) } \\
\text { GMM } \\
\text { Domestically- } \\
\text { oriented firms }\end{array}$ & $\begin{array}{c}6) \\
\text { GMM } \\
\text { Internationally } \\
\text {-oriented firms }\end{array}$ \\
\hline INT & $\begin{array}{l}-0.451 \\
(1.251)\end{array}$ & $\begin{array}{l}-0.452 \\
(0.86)\end{array}$ & $\begin{array}{c}-0.6 \\
(0.369)\end{array}$ & $\begin{array}{l}-0.694 \\
(0.582)\end{array}$ & $\begin{array}{c}-0.586^{* * * *} \\
(0.168)\end{array}$ & $\begin{array}{c}-0.785^{* *} \\
(0.35)\end{array}$ \\
\hline GDP & $\begin{array}{c}-0.079 \\
(1.3)\end{array}$ & $\begin{array}{l}-1.031 \\
(0.885)\end{array}$ & $\begin{array}{c}0.044 \\
(0.359)\end{array}$ & $\begin{array}{c}0.955 \\
(0.748)\end{array}$ & $\begin{array}{c}-0.14 \\
(0.212)\end{array}$ & $\begin{array}{c}-0.856^{* * *} \\
(0.422)\end{array}$ \\
\hline LNAGE & $\begin{array}{l}-0.025 \\
(0.018)\end{array}$ & $\begin{array}{l}-0.016 \\
(0.013)\end{array}$ & $\begin{array}{l}-0.02^{* *} \\
(0.010)\end{array}$ & $\begin{array}{c}0.007 \\
(0.012)\end{array}$ & $\begin{array}{l}-0.006 \\
(0.01)\end{array}$ & $\begin{array}{c}-0.193 * * * \\
(0.027)\end{array}$ \\
\hline SIZE & $\begin{array}{c}0.011 \\
(0.009)\end{array}$ & $\begin{array}{c}0.017 * * * * \\
(0.005)\end{array}$ & $\begin{array}{c}0.002 \\
(0.004)\end{array}$ & $\begin{array}{l}-0.004 \\
(0.008)\end{array}$ & $\begin{array}{c}-0.024 * * * \\
(0.004)\end{array}$ & $\begin{array}{c}0.003 \\
(0.008)\end{array}$ \\
\hline $\begin{array}{l}\text { LEV } \\
\text { (IVLEV) }\end{array}$ & & & $\begin{array}{l}-0,126 \\
(0.313)\end{array}$ & $\begin{array}{l}-0.090 \\
(0.476)\end{array}$ & $\begin{array}{c}-0.090^{* * *} \\
(0.024)\end{array}$ & $\begin{array}{c}-0.23 * * * \\
(0.044)\end{array}$ \\
\hline $\begin{array}{l}\text { TANGIBI } \\
\text { LITY }\end{array}$ & $\begin{array}{l}-0.054 \\
(0.054)\end{array}$ & & & & & \\
\hline Constant & $\begin{array}{c}0.278 \\
(0.288) \\
\end{array}$ & $\begin{array}{c}0.049 \\
(0.184) \\
\end{array}$ & $\begin{array}{l}0.184 * \\
(0.100) \\
\end{array}$ & $\begin{array}{l}0.230^{*} \\
(0.138) \\
\end{array}$ & & \\
\hline $\begin{array}{l}\text { No of obs } \\
\text { Adj. R-sq }\end{array}$ & $\begin{array}{c}359 \\
20.023 \\
\end{array}$ & $\begin{array}{c}604 \\
26.843 \\
\end{array}$ & $\begin{array}{c}359 \\
1.534 \\
\end{array}$ & $\begin{array}{c}604 \\
10.68\end{array}$ & 359 & 604 \\
\hline $\begin{array}{l}\text { Arellano - } \\
\text { Bond test }\end{array}$ & $\begin{array}{l}\text { AR (1) } \\
\text { P-value } \\
\text { AR(2) } \\
\text { P-value }\end{array}$ & & & & $\begin{array}{l}-2.82 \\
(0.005) \\
-0.14 \\
(0.631)\end{array}$ & $\begin{array}{l}-3.47 \\
(0.001) \\
-1.85 \\
(0.405)\end{array}$ \\
\hline $\begin{array}{l}\text { Sargan test } \\
\text { P-value }\end{array}$ & & & & & $\begin{array}{l}19,68 \\
(0.942)\end{array}$ & $\begin{array}{l}48.58 \\
(0.407)\end{array}$ \\
\hline
\end{tabular}

Symbol ***,**, and $*$ denote significance at the $1 \%, 5 \%$ and $10 \%$ level.

A more reasonable explanations about the reverse relationship of the two factors was proposed by [35]. They said that the costs of production expansion, investing in foreign markets are greater than the benefits achieved in the future. Therefore, the authors believe that internationalization will decrease in the rate of profit on total assets.

Besides, some authors like [36], and [37] argued that the relationship between internationalization and performance are reverse U-shaped. This asserts that in the early stages of the internationalization, the benefits get higher than all the production costs. However, after that period, costs will increases that make enterprises' performance declined.

In addition, [36] also provides the explanation for the negative relationship between internationalization and performance in emerging markets. They said that the first phase of international expansion provides enterprises with more opportunities for investment and development. It's easy to exploit potential resources from companies in foreign country. However, due to continued expansion, an increase in transaction costs led to a decline in manufacturing activity. So, the curve will show a slope up (positively) initially and then bent down (negative) on a later stage. 
To strengthen the hypothesis: internationalization influences the relationship between financial leverage and performance, we continue to divide the sample, based on total assets to provide further results about the relationship of small and large enterprises.

\subsection{The impact of the financial leverage on performance by scale}

In table 7, four subsamples include small internationally - oriented firms, large internationally oriented firms, small domestically - oriented firms, large domestically - oriented firms. The results show that the negative effect of financial leverage to the performance of small domestically-oriented firms ( $\beta$ $=|-0083|)$ is approximate to large domestically-oriented firms $(\beta=|-0.08|)$. This result is consistent with [15]

Also, we found that the negative effect in small internationally-oriented firms $(\beta=|-0443|)$ is larger than in large internationally-oriented firms $(\beta=|-0162|)$. This results are similar to [16], [20], [21], [19], and [23]. They explained that the international companies can take advantage of large scale to reduce negative effects on relationships between the leverage and performance.

The sign of the relationship between leverage and firm's performance does not still change when we consider four subsamples. It confirms the robustness of research's results. Besides, the research also use Arellano-Bond test with AR (1) and AR (2), and Sargan test to ensure the fitness of the model. The pvalue of $\mathrm{AR}(2)$ tests are larger than 0.01 that mean we cannot reject null hypothesis. We also conduct over - identifying restrictions test through Sargan test. The results show that there are no autocorrelation level 2 in residuals and instrument variables are suitable which is expect to give reliable regression results in the models.

Table 7: GMM results for 4 subsamples

\begin{tabular}{|c|c|c|c|c|}
\hline & $\begin{array}{l}\text { Small Domestic } \\
\text { Firms }\end{array}$ & $\begin{array}{l}\text { Large Domestic } \\
\text { Firms }\end{array}$ & $\begin{array}{l}\text { Small International } \\
\text { Firms }\end{array}$ & $\begin{array}{c}\text { Large } \\
\text { International } \\
\text { Firms }\end{array}$ \\
\hline LEV & $\begin{array}{c}-0.083 * * * \\
(0.026)\end{array}$ & $\begin{array}{c}-0.08 * * \\
(0.041)\end{array}$ & $\begin{array}{c}-0.443 * * * \\
(0.072)\end{array}$ & $\begin{array}{c}-0.162 * * * \\
(0.055)\end{array}$ \\
\hline INT & $\begin{array}{l}-0.259 \\
(0.185)\end{array}$ & $\begin{array}{c}-1.035^{* * * *} \\
(0.287)\end{array}$ & $\begin{array}{l}-0.677 \\
(0.431)\end{array}$ & $\begin{array}{c}-0.979 * \\
(0.529)\end{array}$ \\
\hline GDP & $\begin{array}{l}-0.212 \\
(0.239)\end{array}$ & $\begin{array}{c}0.120 \\
(0.363)\end{array}$ & $\begin{array}{l}-0.759 \\
(0.537)\end{array}$ & $\begin{array}{l}-0.203 \\
(0.651)\end{array}$ \\
\hline LNAGE & $\begin{array}{l}-0.015 \\
(0.013)\end{array}$ & $\begin{array}{c}0.004 \\
(0.015)\end{array}$ & $\begin{array}{l}-0.056 \\
(0.040)\end{array}$ & $\begin{array}{c}-0.322 * * * \\
(-0.040)\end{array}$ \\
\hline SIZE & $\begin{array}{c}-0.024 * * * \\
(0.007) \\
\end{array}$ & $\begin{array}{l}-0.027 \\
(0.006)\end{array}$ & $\begin{array}{l}-0.001 \\
(0.027)\end{array}$ & $\begin{array}{c}0.010 \\
(0.009)\end{array}$ \\
\hline Oberservation number & 165 & 154 & 247 & 290 \\
\hline Adj. R-sq & 0 & 0 & 0 & 0 \\
\hline $\begin{array}{ll}\text { Arellano - } & \text { AR(1) } \\
\text { Bond test } & \text { P-value } \\
\text { Arellano - } & \text { AR(2) } \\
\text { Bond test } & \text { P-value } \\
\text { Sargan test } & \\
\text { P-value } & \\
\end{array}$ & $\begin{array}{c}-2.27 \\
(0.023) \\
-0.76 \\
(0.278) \\
49,47 \\
(0,318) \\
\end{array}$ & $\begin{array}{c}-1.68 \\
(0.093) \\
-0.59 \\
(0.295) \\
19.6 \\
(0.944) \\
\end{array}$ & $\begin{array}{c}-2.77 \\
(0.006) \\
-0.69 \\
(0.493) \\
44.55 \\
(0.468) \\
\end{array}$ & $\begin{array}{c}-2,75 \\
(0.006) \\
-0,69 \\
(0.199) \\
17.89 \\
(0.971) \\
\end{array}$ \\
\hline
\end{tabular}

Symbol ***,**, and * denote significance at the $1 \%, 5 \%$ and $10 \%$ level.

\section{CONCLUSIONS AND POLICY IMPLICATIONS}

The research considers the effect of international trade on the relationship between financial leverage and performance. The results show that there are the negative effects of financial leverage on performance in the future. The paper keeps running the model with two subsamples. That are internationally - oriented firms, and domestically - oriented firms. The results are that the internationalization influences negatively 
the relationship between financial leverage and performance for both domestic and international enterprises. The effect is stronger in internationally - oriented firms than in domestically - oriented firms.

In addition, the research sample is also split into four subsamples which are: large domestically oriented companies and internationally - oriented companies, and the small ones, to verify the effects of business scale on the relationship between financial leverage and performance, using GMM estimation methods. The results showed that the greater business scale will reduce negative effects of financial leverage on the performance of Vietnamese enterprises.

This paper has brought the process of internationalization into financial management with the purpose of helping Vietnamese enterprises reasonably combine the internationalized strategy and capital resource management to increase corporate value in the future. The research results reveal that internationalization can bring many risks to business and causes a decline in firm's performance. Its reasons can be as follow:

One is increasing costs thus reducing business results [38]. The lack of understanding of foreign markets in the early stages of joining the internationalization brings significant risks which can reduce the profits of the business in the international market

Two is increasing the internationalization can increase transaction costs and other costs of processing information, thus reducing the profits of the business [39].

Three is limited ability of managers to adjust the international environment that keeps creating a negative influence on the achievement of the company [40].

Four is that internationalization could lead to agency problems with available excess cash flow in the enterprises. The managers of these companies tend to invest the free cash flow in the project with the net present value (NPV <0) to pursue their own interests [41].

Five is that the existence of an inverse relationship between firms' performance and internationalization by rising the costs of goods and services diversity strategy that tends to be greater than the profits received in the future ([42] and [43]).

From the above, we can see that the diversification of the international companies tend to use excessively their resources and the result is decline in the profitability of the business. Also, according to the results, Vietnamese enterprises should consider carefully the effectiveness of international business. Besides, we can see that Vietnamese enterprises haven't really dominated the foreign markets, and they are still dependent on the goods and materials imported from overseas markets. That will brings more risks for the enterprises having high leverage ratio.

Therefore, we can come to some implications for policymakers. For emerging markets like Vietnam, Governments should devise measures to create favorable conditions for SMEs in export. They can help SMEs reduce the costs of foreign market exploration companies by providing the quality information, or help them reduce advertising costs through promoting countries' image to increase their comparative advantages, combining with appropriate tax and exchange rate policies. Besides, the quality of labor must also be improved through education and training to be able to compete on the international market.

For enterprises, improving their internal resources is the key to succeed. They need to change the habits and the style of work of employees, improve their analytical skills and international business knowledge to adapt to the globalization process. Besides, the directors have to prepare themselves for best understanding the internal and external business situation to quickly adapt to the new changes, and prepare strategies to reduce risks.

\section{REFERENCE}

[1] T. T. X. Lan, Study of the relationship between growth opportunity and leverage finance: Empirical evidence in Vietnam, University of Economics Ho Chi Minh city, 2015

[2] P. T. Thu, Financial leverage, corporate growth and financial strength of the business listed on the Ho Chi Minh securities trading center, University of Economics Ho Chi Minh city, 2016.

[3] D. T. T. Thuy, Assessment of the status of use of leverage financing of non-financial businesses listed in Vietnam, University of Economics Ho Chi Minh city, 2013. 
[4] Margaritis, Psillaki, Capital structure, equity ownership and firm performance, Journal of Banking \& Finance, vol. 34, no. 3, pp. 621-632, 2010.

[5] Cai, Zhang, Leverage change, debt overhang, and stock prices, Journal of Corporate Finance, vol. 17, no. 3, pp. 391-402, 2011.

[6] Giroud, Mueller, Stomper, Westerkamp, Snow and leverage, The Review of Financial Studies, vol. 25, no. 3, pp. 680-710, 2012.

[7] Antoniou, Guney, Paudyal, The determinants of capital structure: capital market-oriented versus bank-oriented institutions, Journal of Financial and Quantitative Analysis, vol. 43, no. 1, pp. 59-92, 2008.

[8] Connelly, Limpaphayom, Nagarajan, Form versus substance: the effect of ownership structure and corporate governance on firm value in Thailand, Journal of Banking \& Finance, vol. 36, no. 6, pp. 1722-1743, 2012.

[9] Coricellia, Driffield, S. Pal, I. Rolandd, When does leverage hurt productivity growth? A firm-level analysis, Journal of International Money and Finance, vol. 31, no. 6, pp. 1674-1694, 2012.

[10] Lang, Ofek, Stulz, Leverage, investment, and firm growth, Journal of Financial Economics, vol. 40, no. 1, pp. 3-29, 1996.

[11] E. Ilyukhin, The impact of financial leverage on firm performance: evidence from Russia, Journal of Corporate Finance Research, vol. 34, no. 2, pp. 24-36, 2015.

[12] S. Vătavu, The Impact of Capital Structure on Financial Performance in Romanian Listed Companies, Procedia Economics and Finance, vol. 32, pp. 1314-1322, 2015.

[13] Z. H. Javed, H. H. Rao, B. Akram, M. F. Nazir, Effect of Financial Leverage on Performance of the Firms: Empirical Evidence from Pakistan, Journal of Economics and Business, vol. 65, no. 1-2, pp. 87-95, 2015.

[14] R. K. Mule, M. S. Mukras, Financial leverage and performance of listed firms in a frontier market: Panel evidence from Kenya, European Scientific Journal, vol. 11, no. 7, pp. 534-550, 2015.

[15] C. Vithessonthi, J. Tongurai, The effect of firm size on the leverage-performance relationship during the financial crisis of 2007-2009, Journal of Multinational Financial Management, vol.29, pp. 1-29, 2015.

[16] D. M. Brock, T.Yaffe, International diversification and performance: The mediating role of implementation. International Business Review, vol. 17, no. 5, pp. 600-615, 2008

[17] A.Goerzen, S.Makino, (2007), Multinational corporation internationalization in the service sector: A study of Japanese trading companies, Journal of International Business Studies, vol. 38, pp. 1149-1169, 2007.

[18] Wan, Yiu, Hoskisson, Kim, The performance implications of relationship banking during macroeconomic expansion and contraction: a study of Japanese banks' social relationships and overseas expansion, Journal of International Business Studies, vol. 39, no. 3, pp. 406-427, 2008

[19] Zander, Where to the multinational? The evolution of technological capabilities in the multinational network, International Business Review, vol. 8, no. 3, pp. 261-291, 1999.

[20] C. Hui, Tansuhaj, Hallagan, M. Cullough, Effects of firm resources on growth in multinationality, Journal of International Business Studies, vol. 38, no. 6, pp. 961-974, 2007

[21] Ganotakis, Love, Export propensity, export intensity and firm performance: The role of the entrepreneurial founding team, Journal of International Business Studies, vol. 43, no. 8, pp. 693-718, 2012. 
[22] S. Zahra, , R. Ireland, M. Hitt, International expansion by new venture firms: international diversity, mode of market entry, technological learning, and performance, Academy of Management Journal, vol. 43, no. 5, pp. 925-950, 2000.

[23] Zhou, $\mathrm{Wu}, \mathrm{Luo}$, Internationalization and the performance of born-global SMEs: the mediating role of social networks, Journal of International Business Studies, vol. 38, no. 4, pp. 673-690, 2007.

[24] Park, Suh, Yeung, Do multinational and domestic corporations differ in their leverage policies?, Journal of Corporate Finance, vol. 20, pp. 115-139, 2013.

[25] K. Eriksson, J. Johanson, A. Majkgaard, D. Sharma, Experiential knowledge and cost in the internationalization process, Journal of International Business Studies, vol. 28, no. 2, pp. 1033-1053, 1997.

[26] Bobilloa, Iturriaga, Gaitec, Firm performance and international diversification: The internal and external competitive advantages, International Business Review, vol. 19, no. 6, pp. 607-618, 2010.

[227] R. García-García, E. García-Canal, M. F. Guillénc, Rapid internationalization and long-term performance: The knowledge link, Journal of World Business, vol.52, no. 1, pp. 97-110, 2017.

[28] J. C. Pinho, C. Prange, The effect of social networks and dynamic internationalization capabilities on international performance, Journal of World Business, vol. 51, no. 3, pp. 391-403, 2016.

[29] J. Kim, M. Hemmert, What drives the export performance of small and medium-sized subcontracting firms? A study of Korean manufacturers, International Business Review, vol. 25, no. 2, pp. 511-521, 2016.

[30] S. Munjal, I. Requejo, S. K.Kunduc. (2018), Offshore outsourcing and firm performance: Moderating effects of size, growth and slack resources, Journal of Business Research [Online]. Available: https://www.sciencedirect.com/science/article/abs/pii/S0148296318300146

[31] J. Nam, X. Liu, E. Lioliou, M. Jeong, Do board directors affect the export propensity and export performance of Korean firms? A resource dependence perspective, International Business Review, vol. 27, no. 1, pp. 269280,2018

[32] H.T.N. Hien, The relationship between the process of internationalization and the performance of manufacturing enterprises in Vietnam, University of Economic Ho Chi Minh city, 2013.

[33] B. B. Nielsen, S. Nielsen, Top management team nationality diversity and firm performance: A multilevel study, Strategic Management Journal, vol. 34, no. 3, pp. 373-382, 2013.

[34] Singla, George, Internationalization and performance: a contextual analysis of Indian firms. Journal of Business Research, vol. 66, no. 12, pp. 2500-2506, 2013.

[35] Geringer, Tallman, Olsen, Product and international diversification among Japanese multinational firm. Strategic Management Journal, vol. 21, no. 1, pp. 51-80, 2000.

[36] Chao, Kumar, The impact of institutional distance on the international diversity-performance relationship, Journal of World Business, vol. 45, no. 1, pp. 93-103, 2010.

[37] Hitt, Hoskisson, Kim, International diversification: effects on innovation and firm performance in productdiversified firms, The Academy of Management Journal, vol. 40, no. 4, pp. 767-798, 1997.

[38] G. George, J. Wiklund, S. A. Zahra, Ownership and internationalization of small firms, Journal of Management, vol. 31, no. 2, pp. 210-233, 2005. 
[39] M. A. Hitt, R. E. Hoskisson, R. D. Ireland, A mid-range theory of the interactive effects of international and product diversification on innovation and performance, The Journal of Management, vol. 20, no. 2, pp. 297326, 1994.

[40] Stulz, Managerial discretion and optimal financing policies, Journal of Financial Economics, vol. 26, pp. 3-27, 1990.

[41] M. C. Jensen, Agency Costs of Free Cash Flow, Corporate Finance, and Takeovers, The American Economic Review, vol. 76, no. 2, pp. 323-329, 1986.

[42] S. Tallman, J. Li, Effects of international diversity and product diversity on the performance of multinational firms, Academic Management Journal, vol. 39, no. 1, pp. 179-196, 1996.

[43] L. G. Franko, Global corporate competition: Who's winning, who's losing, and the R\&D factor as one reason why, Strategic Management Journal, vol. 10, no. 5, pp. 449-474, 1989.

Received on February $1^{\text {st }}$, 2019

Accepted on March 25 $5^{\text {th }}, 2019$ 